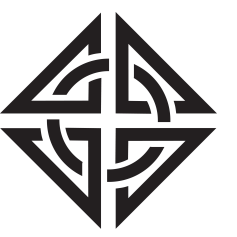

Sharif University of Technology

Scientia Iranica

Transactions A: Civil Engineering

http://scientiairanica.sharif.edu

\title{
A laboratory investigation of suppression of dust from wind erosion using biocementation with Bacillus amyloliquefaciens
}

\author{
M.M. Mohebbia , G. Habibagahia,*, A. Niazi ${ }^{\mathrm{b}}$, and A. Ghahramani ${ }^{\mathrm{a}}$ \\ a. Department of Civil and Environmental Engineering, Shiraz University, Shiraz, P.O. Box 71348-51156, Iran. \\ b. Institute of Biotechnology, Shiraz University, Shiraz, Iran.
}

Received 19 April 2017; received in revised form 15 October 2017; accepted 12 March 2018
KEYWORDS
Wind erosion;
Dust control;
Wind tunnel;
Biocementation;
Calcium carbonate,
Bacillus
amyloliquefaciens.

\begin{abstract}
Dust events are among the serious environmental challenges in some countries. Sustainable solutions can be applied to tackle this problem by considering soil as a living ecosystem. Biocementation based on the production of carbonates by heterotrophic bacteria is one of the favorable methods for suppressing the dust from wind erosion, because this type of bacteria produces calcium carbonate (main product) as well as water and carbon dioxide (by-products). In the present research, bacterial species of Bacillus amyloliquefaciens was sampled for analysis. First, bacteria were cultivated to reach a predetermined concentration. Next, bacterial cells and nutrients in the form of solution were sprayed on the soil surface. Then, samples were tested in a closed-circuit wind tunnel. Three main groups of samples were tested: (1) without sand bombardment and undisturbed soil surface, (2) with sand bombardment and undisturbed soil surface, and (3) without sand bombardment and with disturbed soil surface. The results show that the implemented method for soil stabilization is efficient. Moreover, based on the results of the second group of tests, curing duration, amount of water, temperature-water interaction, and waterbacterial cells interaction were found to be of considerable significance.

(C) 2019 Sharif University of Technology. All rights reserved.
\end{abstract}

\section{Introduction}

Dust events resulting from wind erosion of soil represent an important source of air pollution and environmental challenge. Dust phenomenon has several effects on human life. First, dust influences the atmospheric radiation balance directly or indirectly and, hence, leads to global climatic variations [1]. Second, it

*. Corresponding author: Tel: +9871 36473499;

Fax: +987136743161

E-mail addresses: mohebbino@shirazu.ac.ir (M.M.

Mohebbi); habibg@shirazu.ac.ir (G. Habibagahi);

niazi@shirazu.ac.ir (A. Niazi); ghahrama@shirazu.ac.ir (A. Ghahramani)

doi: $10.24200 /$ sci. 2018.20220 causes air pollution and consequential illnesses such as meningitis, valley fever, and asthma [2]. Third, it is accompanied by economic aspects such as reduction of agricultural production, reduction of sight distance and corresponding dangers, and economic activity halt.

Methods for controlling and suppressing dust from wind erosion can be categorized into two main groups. The first group focuses on separating dust from the air, while the second group tries to suppress particles at the source. The former group suffers from some limitations, the most important of which is lack of efficiency to control suspended particles. The latter group tries to stabilize the soil at the source, which is highly appreciated by researchers.

Stabilization of susceptible soil at the source can be categorized into the following: correct land use 
(depending on the potential of land), retention of soil moisture, vegetation, leaving stubble on farm, windbreak (living and artificial), artificial covers (such as gravel and cobble, oil mulch, and resin emulsions), and use of microorganism [3]. In some methods such as the three first methods and living windbreak, a minimum of moisture and suitable conditions for plant growth are necessary. Furthermore, leaving stubble is restricted to farmlands. When dust is originated from vast regions, the use of artificial covers, such as gravel, cobble, and fiber, is very expensive and uneconomical. Today's growing attention to sustainable development and environmental protection facilitates the use of oil mulch, resin emulsions, and chemical additives.

In recent years, biotechnology has facilitated the use of microorganisms to stabilize the soil considering minimum adverse effects on the environment. Applications of microorganism in dust suppression require a reasonable amount of moisture, which is simultaneously available when microorganism is sprayed on the soil.

Microorganism-based methods are able to cover vast regions in a sufficiently acceptable time using aircraft sprayers. These methods could improve a wide range of soil gradation; examples include data of Maleki et al. [4], Mortensen et al. [5], and RebataLanda [6]. From an economic viewpoint, some of the previous studies published in the literature have shown the potential of using microorganisms to compete with other stabilization methods. For instance, Ivanov and Chu [7] stated that the cost of raw materials for the chemical soil grouting is in the range of $\$ 2$ to $\$ 72$ per cubic meters of soil, whereas the cost of raw materials for the microbial grouting lies in the range of $\$ 0.5$ to $\$ 9.0$ per cubic meters of soil. In addition, Dejong et al. [8] showed that the actual costs of various improvement processes were ambiguous because of rare field applications. However, they compared alternative applications and their potential, considering implementation feasibility, probability of success, cost/viability, and social acceptance of biogeochemical process in the form of a table. In this comparison, dust mitigation control using a biogeochemical process has 18 out of a total score of 20 in general and a score of 4 out of 5 for economic aspect, which is considered as the highest ranking.

Bang et al. [9], Stabnikov et al. [10], Anderson et al. [11], Liu et al. [12], Meyer et al. [13], and O'Brien and Neuman [14] are just a few researchers among others to study soil stabilization using bacteria for dust suppression. In addition, there exist other studies based on which algae, fungi, and enzymes are added to soil for stabilization. For instance, the data of Cuadros et al. [15], Neuman and Maxwell [16], Knorr [17], and Alsanad [18] and Strong [19] are of importance to consider. These types of crusts have several advantages such as flexibility, as compared to biochemical crusts. However, the main drawback of these techniques is their long and repetitive treatments. For example, O'Brien and Neuman [14] treated samples by Nostoc Commune cyanobacteria for a five-week period, and the crusts were fed weekly with Bold Basal Medium and watered daily. The repetition of treatment for large-scale application is obviously time consuming and uneconomical. Moreover, based on Strong [19], the cyanobacteria crusts are weakened in the case of infrequent, insignificant rainfall events, resulting in an increase in vulnerability of soils to wind erosion. These restrictions are serious limitations for long-term and large-scale applications of the above-mentioned researches. In return, the present method does not suffer from these limitations.

One of the overlooked aspects of previous researches in the field of bacteria application for stabilization of soil and suppression of dust is the problem of by-products of reactions. For instance, in several of these investigations, Bacillus spharicus species of bacteria was used, and the fatal ammonia by-product was obtained. In addition, cyanobacteria, algae, and fungi were found to reside deep in the soil profile until sufficient moisture was received [19].

In the present study, Bacillus amyloliquefaciens bacteria are used. These bacteria produce calcium carbonate biocementation as the main product and water and carbon dioxide as by-products as follows:

$\left(\mathrm{CH}_{3} \mathrm{COO}\right)_{2} \mathrm{Ca}+4 \mathrm{O}_{2} \rightarrow \mathrm{CaCO}_{3} \downarrow+3 \mathrm{CO}_{2} \uparrow+3 \mathrm{H}_{2} \mathrm{O}$.

It is evident that carbon dioxide is more acceptable than ammonia by-product. In addition, for the proposed method in this research, the required moisture will be provided simultaneously while bacteria are being sprayed. Furthermore, an attempt has been made to enrich this research by a proper design of experiments to select all significant factors, while the relative importance and influence of these parameters on the mass loss due to wind erosion have been taken into account. Moreover, the samples have been weighted continuously during wind erosion tests in wind tunnel by a 3-component balance to ensure better simulation.

\section{Materials and methods}

\subsection{Materials}

Soil was obtained from a critical wind erosion hotspot located in the south of Iran (Khoormoj $90 \mathrm{~km}$ south east of Bushehr). The gradation curve of soil is illustrated in Figure 1(a). The soil is classified as SPSM based on unified soil classification system and is originated from carbonate rocks. All soil samples were autoclaved before treatment to ensure that the changes in wind erosion potential detected in the tests were solely derived from biocementation by the specified bacteria. The exception is a control sample, which was prepared with unautoclaved soil. 


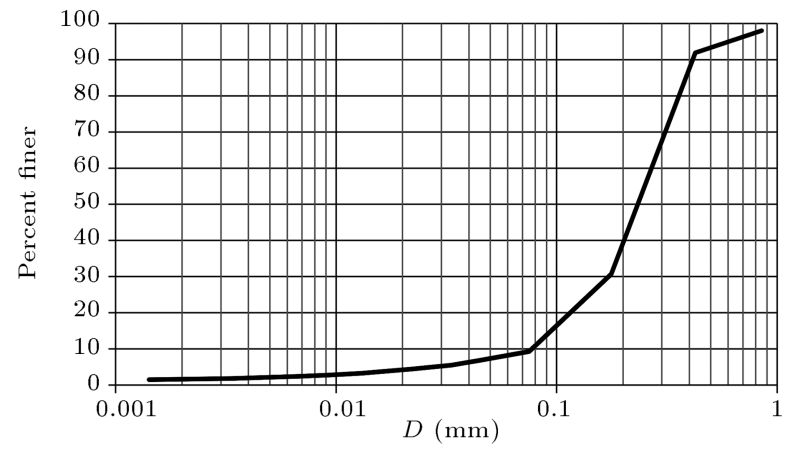

(a)

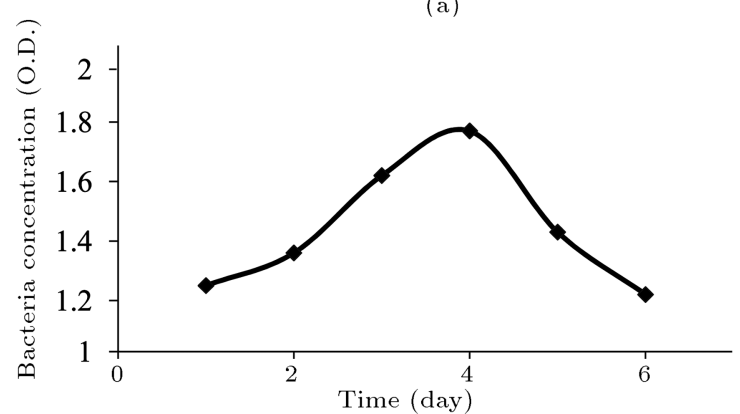

(b)

Figure 1. (a) Soil gradation curve. (b) Bacterial growth curve.

Silica sand with grain distribution between $425 \mu \mathrm{m}$ and $595 \mu \mathrm{m}$ was used for sand bombardment. Several researchers [20-22] have estimated that suspended moving particles in the air are in the range of 70-500 $\mu \mathrm{m}$. Therefore, the selected sand bombardment material lies in a conservative range.

Distilled water was used for soil treatments. Before sample preparation, water was autoclaved to ensure no sign of bacteria present in water.

B. amyloliquefaciens bacterium was selected for this research. This type of bacterium exists naturally in soil. However, for the present study, the lyophilized powder of the bacterial biomass, strain PTCC no. 1732 (other collection no. DSM7, ATCC23350), was prepared from the Iranian Research Organization for Science and Technology (IROST). This strain is aerobic with optimum temperature of $30^{\circ} \mathrm{C}$ for growth. As stated previously, this type of bacteria has advantages over other types in terms of its environmental friendly by-products, and the risk group of $B$. amyloliquefaciens is 1 , which is unlikely to cause disease in human, animals, plants or fungi, according to the German Technical Rules for Biological Agents (TRBA) classification. The bacteria were cultured in LuriaBertani (LB) medium, which involves $1 \%$ tryptone $\left(\right.$ Merck $\left.^{\circledR}\right), 0.5 \%$ yeast extract $\left(\right.$ Merck $\left.^{\circledR}\right)$, and $0.1 \%$ $\mathrm{NaCl}\left(\right.$ Merck $\left.^{\circledR}\right)$. Calcium acetate (Merck ${ }^{\circledR}$ ) was used as an energy source.

\subsection{Methods}

2.2.1. Bacteria culture

B.amyloliquefaciens bacterium was cultured in LB liquid medium inside a shaking incubator with 110 rpm and at $28^{\circ} \mathrm{C}$. Bacterial growth curve is shown in Figure 1(b). Optical Density (O.D.) of bacteria solution was determined by a spectrophotometer (Optima model sp-3000 plus), which was set at a wavelength of $600 \mathrm{~nm}$.

\subsubsection{Sample preparation and treatment}

Soil specimens were prepared in $200 \times 200 \times 50 \mathrm{~mm}$ boxes made of transparent Plexiglas plates. The measured in-situ density of soil is about $15.7 \mathrm{kN} / \mathrm{m}^{3}$. Soil samples were compacted to a density close to in-situ condition. Initial water content of untreated soil is $0.5 \pm 0.1 \%$. Next, the predetermined amounts of bacterial cells (O.D. $=0.75$ and 1.5 in the form of $40 \mathrm{~g}$ solution) and nutrient solution (concentration= 0.05 and $0.1 \mathrm{~g} / \mathrm{lit}$, equivalent to 2 and $4 \mathrm{~g}$ of nutrient in 20 and $40 \mathrm{~g}$ solution) were sprayed on the surface of soil samples. All the water sprayed on samples penetrated in the soil, and no run-off was observed. Finally, samples were cured at a designed temperature and duration. The remaining water contents after treatment of samples were 0.2 to $0.4 \%$. Due to the treatment condition of samples, most of added water was evaporated during the first $24 \mathrm{hr}$ of curing time. After conducting wind tunnel tests, the crust thickness was set to 1 to $2 \mathrm{~cm}$.

\subsubsection{Wind tunnel tests}

A closed-circuit tunnel was used to simulate wind erosion in laboratory. This tunnel is of ISI model 6407 ZAF with $800 \times 800 \mathrm{~mm}$ test section, maximum wind speed of $100 \mathrm{~m} / \mathrm{s}$, and total dimension of $18 \times 6.5 \times 3.8 \mathrm{~m}$. The tunnel is equipped with a 3 component balance that allows the specimen's weight to be recorded continuously during the test.

Seven spires were designed based on Irwin [23] to simulate boundary layer and wind velocity profile in the wind tunnel similar to land surface. The spires were installed $87.7 \mathrm{~cm}$ upstream of soil sample. The generation of desired vertical wind velocity profile and the transversal uniformity of wind profile in the test section were verified by pitot tube measurements at several points.

In order to conduct a continual measurement of soil erosion during the wind tunnel test, the sample box was kept in balance so that the sample weight could be measured continuously without the influence of lift force. Three main groups of tests were carried out: (1) without sand bombardment and undisturbed soil surface (Group A), (2) with sand bombardment and undisturbed soil surface (Group B), and (3) without sand bombardment and disturbed soil surface (Group C).

\section{Group A tests}

In these tests, first, wind velocity was raised to $30 \mathrm{~m} / \mathrm{s}$; then, soil samples were exposed to this flow for 10 


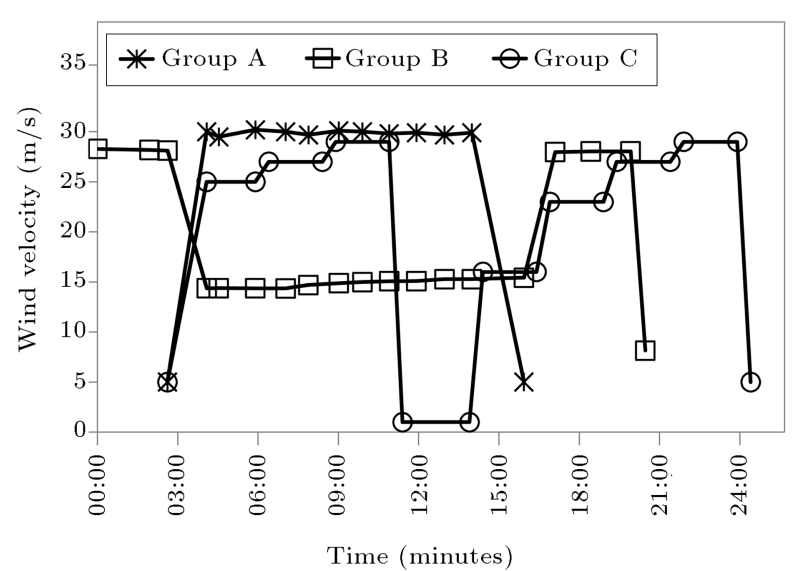

Figure 2. Typical wind velocity in different groups of tests.

minutes. Typical wind velocity graphs for all triple groups of tests are illustrated in Figure 2.

\section{Group B tests}

Several researches have used different mass fluxes for sand bombardment; for instance, Neuman et al. [24] used $0.007 \mathrm{~kg} / \mathrm{m} / \mathrm{s}$; Langston and Neuman [25] $0.015 \mathrm{~kg} / \mathrm{m} / \mathrm{s}$; Rice and McEwan [26] $0.002 \mathrm{~kg} / \mathrm{m}^{2} / \mathrm{s}$; Zobeck [27] 0.01, 0.025, and $0.05 \mathrm{~kg} / \mathrm{m} / \mathrm{s} ;$ Houser and Nickling [28] 0.0026 to $0.023 \mathrm{~kg} / \mathrm{m} / \mathrm{s} ;$ Neuman and Maxwell [16] $0.014 \mathrm{~kg} / \mathrm{m} / \mathrm{s}$. In the present research, due to selected wind velocity for wind erosion test (14 to $15 \mathrm{~m} / \mathrm{s}$ ), the mass flux of sand bombardment was considered to be about $0.01 \mathrm{~kg} / \mathrm{m} / \mathrm{s}(120 \mathrm{gr} / \mathrm{min}$ for each sample).

As mentioned earlier, the grain diameter of sand bombardment material ranged between $425 \mu \mathrm{m}$ and $595 \mu \mathrm{m}$. The bombardment was performed by a separating funnel, a steel tube connector, and a modified upholstery nozzle. Details of the sand bombardment system were determined through a few preliminary tests. In this group of tests, at first, wind velocity was raised to $29 \mathrm{~m} / \mathrm{s}$, and the soil samples were exposed to this flow for 2 minutes. Subsequently, the wind velocity was lowered to $14 \mathrm{~m} / \mathrm{s}$, followed by sand bombardment for a period of 9 minutes at a wind velocity of 14 to $15 \mathrm{~m} / \mathrm{s}$. At the end of sand bombardment stage, the wind velocity was raised again to $28 \sim 29 \mathrm{~m} / \mathrm{s}$, and the soil samples were exposed to this flow for 3 minutes before the test ends. Variation of wind velocity is illustrated in Figure 2.

\section{Group $C$ tests}

For Group C, wind velocity rates were raised stepwise to 25,27 , and $29 \mathrm{~m} / \mathrm{s}$ (see Figure 2). Then, wind velocity was lowered to zero. A disturbance was created at the center of sample surface by a pocket vane shear apparatus (Gilson ${ }^{\circledR}$ model HM-504A). Finally, the velocity was raised again in four steps (as shown in Figure 2), and each step lasted for 2 minutes.

\subsubsection{Design of experiments}

Five main factors should be considered to evaluate the performance of biological calcium carbonate precipitation on the soil surface are: temperature, bacterial population per unit surface area (concentration and volume of bacterial solution), amount of available nutrient for bacteria, moisture on the soil surface, and curing time (available time for calcium carbonate precipitation by bacteria before soil is exposed to wind shear force). To determine levels of each factor, the following considerations should be taken into account:

1. Temperature levels: Optimum temperature for cultivation of $B$. amyloliquefaciens bacterium is $30^{\circ} \mathrm{C}$. Sources of dust are often located in arid and desert regions where the temperature may reach a point higher than the optimum temperature. The above-mentioned reasons led to two temperature levels: $28^{\circ} \mathrm{C}$ (close to optimum temperature of bacterial growth cultivation) and $37^{\circ} \mathrm{C}$. Additional temperature levels were considered for Group B experiments to study high temperature effects $\left(50^{\circ} \mathrm{C}\right)$ and outdoor conditions $\left(7^{\circ} \mathrm{C}\right.$ to $\left.18^{\circ} \mathrm{C}\right)$;

2. Bacterial concentration: Soil samples were treated at 0.75 and 1.5 levels of Optical Density (O.D.) and $40 \mathrm{cc}$ bacterial solution per sample. As Figure 1(b) shows, 0.75 O.D. is a concentration level that can be obtained sooner than one day, and 1.5 O.D. is a level of concentration in which bacterial concentration is stable during a considerable period of time. The former level can be used as an alternative for urgent use in field applications, while the latter level can be applied when a more stable level in a vast region is intended;

3. Nutrient: In terms of cost, the most expensive component is the nutrient (calcium acetate). It was tried to make this method a more competitive alternate against other methods by decreasing the amount of nutrient per unit area. Thus, for treatments of samples, nutrient levels were considered as low as 0.05 and $0.1 \mathrm{~kg} / \mathrm{m}^{2}$ (2 and $4 \mathrm{~g} /$ sample);

4. Soil moisture: Water not only facilitates penetration of bacteria and nutrient into soil pores, but also prepares an appropriate medium for bacteria to live. Of note, a huge amount of water can lead to an uneconomical design in terms of required water to carry and spray. In some traditional methods such as oil mulches, $2 \mathrm{lit} / \mathrm{m}^{2}$ is a normal dosage; thus, the total amount of sprayed water on the soil surface was selected at 2 levels of 1.5 and $2 \mathrm{lit} / \mathrm{m}^{2}$ (60 and $80 \mathrm{cc} /$ sample);

5. Curing time: The short curing time of treated samples results in partial stabilization and, finally, overestimation of wind erosion. On the other hand, the long curing time leads to underestimation of 
the amount of laboratory erosion compared to field wind erosion, owing to the controlled temperature and other conditions in the laboratory. Today, due to recent advances in meteorology that have made it possible to forecast weather conditions for the next 7 to 10 days, field application can be undertaken while the probability of occurrence of imminent strong wind is low. Keeping the above-mentioned explanation in mind, two levels of 3 and 7 days were considered to cover all the possibilities.

Based on the afore-mentioned factors and their levels, a full factorial design of experiments led to 32 tests in each group. A proper statistical design can reduce the required tests while ensuring the validity of the results of the remaining tests. The L12 array of Taguchi was chosen as an experiment design in this research. Therefore, the tests were reduced from 32 to 12. Of note, for Group A, only 8 samples were tested since nominal erosions were observed in this group. Moreover, for Group B, few lime treated samples were tested to compare performances of the two methods.

\subsection{Complementary tests}

In order to ensure that changes in erodibility of tested soil samples result from biological carbonate cementation, two sets of tests were carried out on treated and untreated samples: (1) Calcium Carbonate Equivalent (CCE) tests based on ASTM-D4373 standard; (2) Energy dispersive X-Ray Diffraction (XRD) analysis.

Moreover, Scanning Electron Microscope (SEM) images that can capture a better understanding of bonding formation between soil particles were adopted. For this purpose, SEM of Cambridge model S360 was employed.

\section{Results and discussion}

Table 1 indicates the results of Group A tests. The small amount of erosion in these tests (smaller than $0.0125 \mathrm{~g} / \mathrm{cm}^{2}$ ) proves the efficiency of the proposed treatments for this group of tests. Remediation is defined as follows:

$$
\begin{aligned}
& \text { Remediation }(\%) \\
& =\frac{\text { Untreated mass loss }- \text { Treated mass loss }}{\text { Untreated mass loss }} \times 100 .
\end{aligned}
$$

By using this definition and considering mass loss of untreated sample as $6.825 \mathrm{~g} / \mathrm{cm}^{2}$, remediation percentages are shown in the last column of Table 1.

Table 2 demonstrates the results of wind erosion tests with sand bombardment (Group B). In this table, 12 main samples (rows 1 to 12), 6 negative control samples (rows 13 to 18), 7 samples covering different curing conditions (rows 19 to 25), and 2 samples which are focused on lime stabilization method (rows 26 and 27) are addressed.

Table 3 lists the analysis of variance (ANOVA) for 12 main samples and contributors. Based on this table, among the contributors including five treatment factors and two-factor interactions, curing time, water, temperature-water interaction, and bacteriawater interaction are significant with $p$-value less than 0.05. The normal probability plot of residuals is demonstrated in Figure 3(a). The points on this plot lie reasonably close to a straight line, lending support to the conclusion that the above-mentioned factors and interactions are the only significant effects, and the underlying assumptions of the analysis are satisfied. Furthermore, three normality tests, including Anderson-Darling, Ryan-Joiner, and KolmogrovSmirnov tests, confirm quantitatively the normality hypothesis again. Plot of residuals versus predicted mass loss, shown in Figure 3(b), is satisfactory, and the assumption of variance equality is confirmed.

Each factor is coded according to the equation:

\begin{tabular}{|c|c|c|c|c|c|c|c|c|}
\hline \multirow{2}{*}{\multicolumn{2}{|c|}{$\begin{array}{c}\text { Sample } \\
\text { no. }\end{array}$}} & \multicolumn{5}{|c|}{ Treatment } & \multirow[b]{2}{*}{$\begin{array}{c}\text { Mass } \\
\text { loss } \\
\left(\mathrm{g} / \mathrm{cm}^{2}\right)\end{array}$} & \multirow[b]{2}{*}{$\begin{array}{c}\text { Remediation } \\
(\%)\end{array}$} \\
\hline & & $\begin{array}{c}\text { Temperature } \\
\left({ }^{\circ} \mathrm{C}\right)\end{array}$ & $\begin{array}{c}\text { Bacteria } \\
\text { concentration } \\
\text { (O.D.) }\end{array}$ & $\begin{array}{c}\text { Nutrient } \\
\text { (g/sample) }\end{array}$ & $\begin{array}{c}\text { Water } \\
\text { (g/sample) }\end{array}$ & $\begin{array}{l}\text { Curing } \\
\text { (days) }\end{array}$ & & \\
\hline 1 & $8-1$ & 28 & 0.75 & 4 & 80 & 7 & 0.0050 & 99.9 \\
\hline 2 & $8-2$ & 28 & 0.75 & 4 & 80 & 7 & 0.0025 & 100.0 \\
\hline 3 & $12-1$ & 28 & 1.5 & 2 & 80 & 7 & 0.0025 & 100.0 \\
\hline 4 & $12-2$ & 28 & 1.5 & 2 & 80 & 7 & 0.0125 & 99.8 \\
\hline 5 & $20-1$ & 37 & 0.75 & 2 & 80 & 7 & 0.0050 & 99.9 \\
\hline 6 & $20-2$ & 37 & 0.75 & 2 & 80 & 7 & 0.0025 & 100.0 \\
\hline 7 & $22-1$ & 37 & 0.75 & 4 & 60 & 7 & 0.0100 & 99.9 \\
\hline 8 & $22-2$ & 37 & 0.75 & 4 & 60 & 7 & 0.0050 & 99.9 \\
\hline
\end{tabular}

Table 1. Specifications and results of Group A tests. 
Table 2. Specifications and results of Group B tests.

\begin{tabular}{|c|c|c|c|c|c|c|c|c|c|}
\hline \multirow{2}{*}{\multicolumn{2}{|c|}{$\begin{array}{c}\text { Sample } \\
\text { no. }\end{array}$}} & \multicolumn{5}{|c|}{ Treatment } & \multirow[b]{2}{*}{$\begin{array}{c}\text { Mass } \\
\text { loss } \\
\left(\mathrm{g} / \mathrm{cm}^{2}\right)\end{array}$} & \multirow[b]{2}{*}{$\begin{array}{c}\text { Remediation } \\
(\%)\end{array}$} & \multirow[b]{2}{*}{ Comment } \\
\hline & & $\begin{array}{c}\text { Temperature } \\
\left({ }^{\circ} \mathrm{C}\right)\end{array}$ & $\begin{array}{c}\text { Bacteria } \\
\text { concentration } \\
\text { (O.D.) }\end{array}$ & $\begin{array}{c}\text { Nutrient } \\
\text { (g/sample) }\end{array}$ & $\begin{array}{c}\text { Water } \\
(\mathrm{g} / \text { sample) }\end{array}$ & $\begin{array}{l}\text { Curing } \\
\text { (days) }\end{array}$ & & & \\
\hline 1 & $18-2 \mathrm{M}$ & 28 & 0.75 & 2 & 60 & 3 & 0.0825 & 97.6 & Main test \\
\hline 2 & $18-1 \mathrm{M}$ & 28 & 0.75 & 2 & 60 & 3 & 0.0650 & 98.1 & Main test \\
\hline 3 & $24-2$ & 28 & 0.75 & 4 & 80 & 7 & 0.3375 & 90.0 & Main test \\
\hline 4 & $12-1 \mathrm{M}$ & 28 & 1.5 & 2 & 80 & 7 & 0.1175 & 96.5 & Main test \\
\hline 5 & $14-1 \mathrm{M}$ & 28 & 1.5 & 4 & 60 & 7 & 0.0050 & 99.9 & Main test \\
\hline 6 & $15-\mathrm{M}$ & 28 & 1.5 & 4 & 80 & 3 & 0.3150 & 90.7 & Main test \\
\hline 7 & $20-1 \mathrm{M}$ & 37 & 0.75 & 2 & 80 & 7 & 0.2250 & 93.4 & Main test \\
\hline 8 & $6-2$ & 37 & 0.75 & 4 & 60 & 7 & 0 & 100.0 & Main test \\
\hline 9 & $23-\mathrm{M}$ & 37 & 0.75 & 4 & 80 & 3 & 0.5350 & 84.2 & Main test \\
\hline 10 & $10-2$ & 37 & 1.5 & 2 & 60 & 7 & 0.1025 & 97.0 & Main test \\
\hline 11 & $27-2 \mathrm{M}$ & 37 & 1.5 & 2 & 80 & 3 & 0.2400 & 92.9 & Main test \\
\hline 12 & $29-2 \mathrm{M}$ & 37 & 1.5 & 4 & 60 & 3 & 0.5475 & 83.8 & Main test \\
\hline 13 & $39-1 \mathrm{M}$ & 37 & 0 & 0 & 80 & 3 & 2.4250 & 28.5 & $\begin{array}{c}\text { Negative } \\
\text { control }\end{array}$ \\
\hline 14 & $39-2 \mathrm{M}$ & 37 & 0 & 0 & 80 & 3 & 3.3900 & 0.0 & $\begin{array}{c}\text { Negative } \\
\text { control }\end{array}$ \\
\hline 15 & $35-1 \mathrm{M}$ & 37 & 0 & 2 & 80 & 3 & 0.9475 & 72.1 & $\begin{array}{c}\text { Negative } \\
\text { control }\end{array}$ \\
\hline 16 & $37-1 \mathrm{M}$ & 37 & 0 & 4 & 80 & 3 & 1.0375 & 69.4 & $\begin{array}{c}\text { Negative } \\
\text { control }\end{array}$ \\
\hline 17 & $44-1 \mathrm{M}$ & 37 & 0.75 & 0 & 80 & 3 & 0.1950 & 94.2 & $\begin{array}{c}\text { Negative } \\
\text { control }\end{array}$ \\
\hline 18 & $45-1 \mathrm{M}$ & 37 & 1.5 & 0 & 80 & 3 & 0.1375 & 95.9 & $\begin{array}{c}\text { Negative } \\
\text { control }\end{array}$ \\
\hline 19 & $27 \mathrm{H}$ & 50 & 1.5 & 2 & 80 & 3 & 0.1475 & 95.6 & $\begin{array}{c}\text { High } \\
\text { temperature } \\
\text { condition }\end{array}$ \\
\hline 20 & $29 \mathrm{H}$ & 50 & 1.5 & 4 & 60 & 3 & 1.1600 & 65.8 & $\begin{array}{c}\text { High } \\
\text { temperature } \\
\text { condition }\end{array}$ \\
\hline 21 & $27-1 \mathrm{~F}$ & $\mathrm{a}$ & 1.5 & 2 & 80 & 3 & 0.2775 & 91.8 & $\begin{array}{l}\text { Outdoor } \\
\text { condition }\end{array}$ \\
\hline 22 & $27-2 \mathrm{~F}$ & $\mathrm{a}$ & 1.5 & 2 & 80 & 3 & 0.2900 & 91.4 & $\begin{array}{l}\text { Outdoor } \\
\text { condition }\end{array}$ \\
\hline 23 & $29-1 \mathrm{~F}$ & a & 1.5 & 4 & 60 & 3 & 0.5900 & 82.6 & $\begin{array}{l}\text { Outdoor } \\
\text { condition }\end{array}$ \\
\hline 24 & $29-2 \mathrm{~F}$ & $\mathrm{a}$ & 1.5 & 4 & 60 & 3 & 0.4750 & 86.0 & $\begin{array}{l}\text { Outdoor } \\
\text { condition }\end{array}$ \\
\hline 25 & $27 \mathrm{U}$ & 37 & 1.5 & 2 & 80 & 3 & 0.1250 & 96.3 & $\begin{array}{c}\text { Unautoclaved } \\
\text { soil }\end{array}$ \\
\hline 26 & $27 \mathrm{~A}$ & 37 & 0 & $2^{\mathrm{b}}$ & 80 & 3 & 5.4600 & $(-61.1)$ & $\begin{array}{c}\text { Lime } \\
\text { treatment }\end{array}$ \\
\hline 27 & $29 \mathrm{~A}$ & 37 & 0 & $4^{\mathrm{b}}$ & 60 & 3 & 1.7950 & 47.1 & $\begin{array}{c}\text { Lime } \\
\text { treatment }\end{array}$ \\
\hline
\end{tabular}

a: Outdoor condition, temperature varying from $7^{\circ} \mathrm{C}$ to $18^{\circ} \mathrm{C}$

b: Lime content for lime treated samples 
Table 3. Analysis of variance (ANOVA) for the main samples in Group B.

\begin{tabular}{lcccccc}
\hline \multicolumn{1}{c}{ Source } & Sum of squares & df & Mean square & $\boldsymbol{F}$-value & $\begin{array}{c}\boldsymbol{p} \text {-value } \\
\text { Prob }>\mathbf{F}\end{array}$ & Significance \\
\hline Model & 0.3741 & 6 & 0.0623 & 18.19 & 0.0030 & Significant \\
$T:$ Temperature & 0.0043 & 1 & 0.0043 & 1.27 & 0.3114 & \\
$B:$ Bactria & 0.0039 & 1 & 0.0039 & 1.14 & 0.3343 & \\
$W:$ Water & 0.0780 & 1 & 0.0780 & 22.76 & 0.0050 & \\
$C:$ Curing & 0.2014 & 1 & 0.2014 & 58.75 & 0.0006 & \\
$T \times W$ & 0.0565 & 1 & 0.0565 & 16.48 & 0.0097 & \\
$B \times W$ & 0.1334 & 1 & 0.1334 & 38.91 & 0.0016 & \\
Residual & 0.0171 & 5 & 0.0034 & & & \multirow{2}{*}{ Not significant } \\
Lack of fit & 0.0170 & 4 & 0.0042 & 27.73 & 0.1414 & \\
Pure error & 0.0002 & 1 & 0.0002 & & & \\
\hline
\end{tabular}

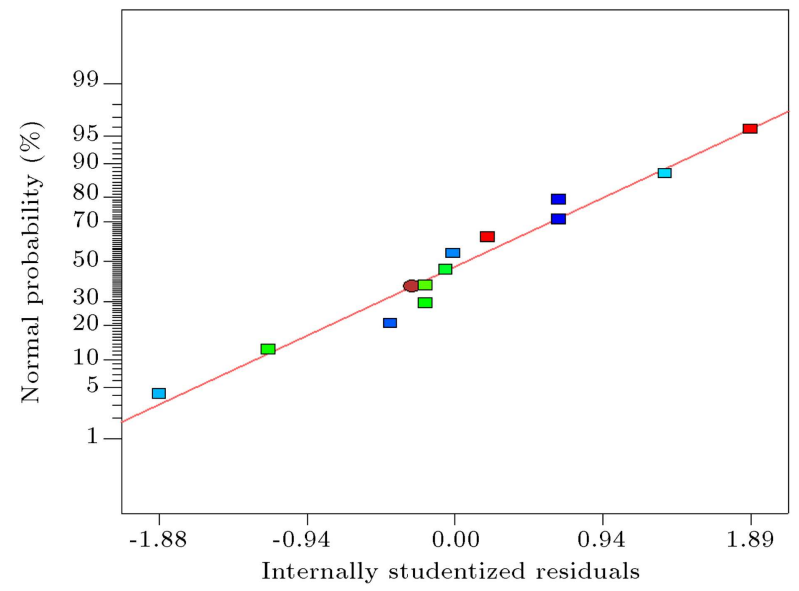

(a)

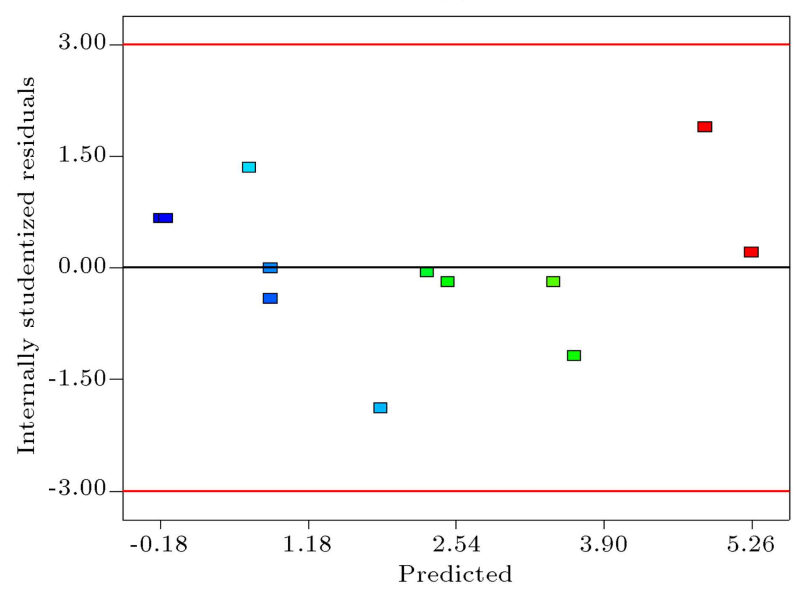

(b)

Figure 3. (a) Normal probability plot of residuals of the main samples in Group B. (b) Plot of residuals versus predicted mass loss of the main samples in Group B.

$$
\bar{x}_{i}=\frac{X_{i}-\left(X_{i, \max }+X_{i, \min }\right) / 2}{\left(X_{i, \max }-X_{i, \min }\right) / 2},
$$

where $\bar{x}_{i}$ is the coded value of $X_{i}$ factor; $X_{i, \max }$ and $X_{i, \text { min }}$ are the values of factor at maximum and minimum levels, respectively. Values range from $28^{\circ} \mathrm{C}$ to $37^{\circ} \mathrm{C}$ for temperature $(T)$, from 0.75 O.D. to 1.5
O.D. for bacteria concentration $(B)$, from $60 \mathrm{~g} /$ sample to $80 \mathrm{~g} /$ sample for water $(W)$, and from 3 days to 7 days for curing time $(C)$.

The following relationship defines the role of contributors in mass loss based on statistical analysis in terms of coded factors:

$$
\begin{aligned}
\operatorname{mass} \operatorname{loss} & \left(\mathrm{gr} / \mathrm{cm}^{2}\right) \\
& =0.210+0.020 \times \bar{T}-0.019 \times \bar{B}+0.081 \\
& \times \bar{W}-0.15 \times \bar{C}-0.079 \\
& \times \bar{T} \times \bar{W}-0.120 \times \bar{B} \times \bar{W}
\end{aligned}
$$

where $\bar{T}, \bar{B}, \bar{W}$, and $\bar{C}$ are temperature, bacteria concentration, water, and curing time factors in the coded form, respectively.

Coded expressing factors have an advantage: Their coefficients are meaningful, and their relative impact can be assessed by comparing them directly. The following points are deduced from this relationship:

1. Curing time factor has the highest significant effect on wind erosion reduction in the present method;

2. Water shows its contributions not only in the form of a single factor, but also in the form of its interactions with temperature and bacteria. Thus, for accurate interpretation of water effects, it is necessary to incorporate interactions:

(a) Figure 4(a) illustrates the temperature-water interaction graph, which demonstrates that raising temperature does not have negative effect on soil stabilization, provided that the amount of applied water is close to its upper limit, as given in Table 2. On the contrary, increasing temperature leads to greater mass loss and lower efficiency as long as used water is close to its lower limit;

(b) Bacteria-water interaction is illustrated in Figure $4(\mathrm{~b})$, indicating that in the case of using upper range of water factor, increasing bacteria 
causes a decrease in mass loss, while, in the case of using lower range of water factor, increasing bacteria also leads to an increase in mass loss;

Negative control tests, including Samples 39-1M and $39-2 \mathrm{M}$ in Table 2, that had no bacteria and nutrient experienced mass losses of $2.4250 \mathrm{~g} / \mathrm{cm}^{2}$ and $3.3900 \mathrm{~g} / \mathrm{cm}^{2}$, which are substantially larger than the mass losses of treated samples. The meaningful differences of wind erosion in treated and untreated samples can be visualized by redrawing a bacteriawater interaction diagram, as shown in Figure 4(c). This finding reemphasizes the efficiency of the proposed approach. Negative control tests, including Samples $35-1 \mathrm{M}$ and $37-1 \mathrm{M}$ (samples without bacteria), demonstrated $0.9475 \mathrm{~g} / \mathrm{cm}^{2}$ and $1.0375 \mathrm{~g} / \mathrm{cm}^{2}$ mass losses, while negative control tests, Samples 44-1M and 451M (samples without nutrient), showed $0.1950 \mathrm{~g} / \mathrm{cm}^{2}$

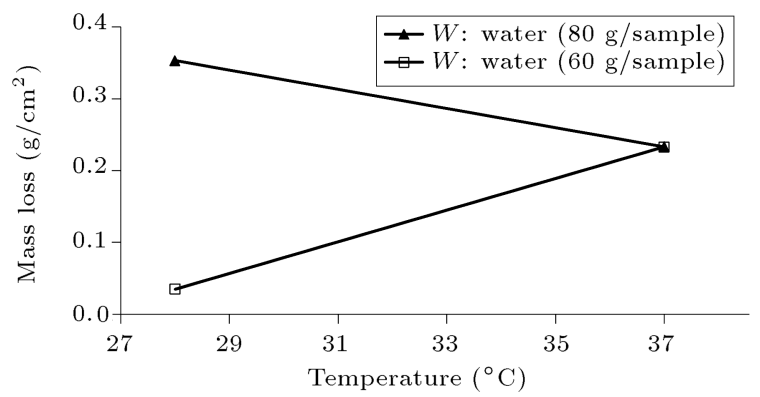

(a)

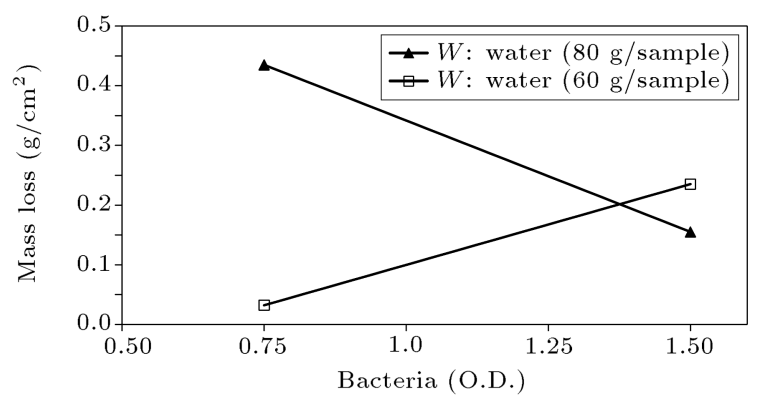

(b)

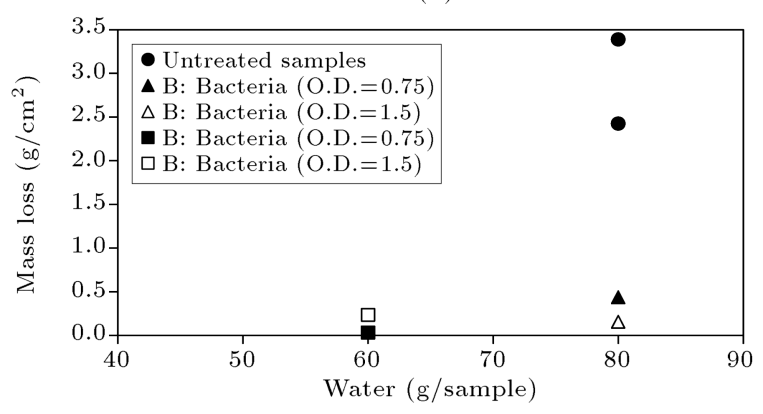

(c)

Figure 4. (a) Temperature-water interaction diagram of mass loss of the main samples in Group B. (b)

Bacteria-water interaction diagram of mass loss of the main samples in Group B. (c) Bacteria-water interaction diagram of mass loss of untreated and the main samples in Group B. and $0.1375 \mathrm{~g} / \mathrm{cm}^{2}$ mass losses, respectively. These tests confirm the results of ANOVA in which bacteria are represented as a contributing factor, while nutrient factor is not statistically a significant factor.

Samples $27 \mathrm{H}$ and $29 \mathrm{H}$ were similar to $27-2 \mathrm{M}$ and 29-2M, respectively; curing temperature of the former samples was $50^{\circ} \mathrm{C}$ instead of $37^{\circ} \mathrm{C}$. The amounts of erosion in Samples $27 \mathrm{H}$ and $27-2 \mathrm{M}$ (with a high level of water factor) were $0.1475 \mathrm{~g} / \mathrm{cm}^{2}$ and $0.2400 \mathrm{~g} / \mathrm{cm}^{2}$, while the mass losses in Samples $29 \mathrm{H}$ and 29-2M (with a low level of water factor) were $1.1600 \mathrm{~g} / \mathrm{cm}^{2}$ and $0.5475 \mathrm{~g} / \mathrm{cm}^{2}$, respectively. Therefore, with the higher amount of water, an increase in temperature gave rise to a reduction in mass loss in Sample 2 $7 \mathrm{H}$, as compared to $27-2 \mathrm{M}$. However, with the lower amount of water, an increase in temperature led to an increase in mass loss in Sample $29 \mathrm{H}$, as compared to 29-2M. These variations could be expected based on the interpretation of temperature-water interaction stated previously.

It is very important to investigate the applicability of the proposed method in the field. Thus, additional experiments were planned, and Samples 27$1 F, 27-2 F, 29-1 F$, and $29-2 F$ were tested. Samples $27-1 \mathrm{~F}$ and $27-2 \mathrm{~F}$ are the same as Sample 27-2M; however, they were cured in the outdoor condition. In addition, Samples $29-1 \mathrm{~F}$ and $29-2 \mathrm{~F}$ are treated in the same condition as $29-2 \mathrm{M}$, yet under the outdoor condition. In the outdoor condition, the samples were exposed to the ambient condition with temperature varying from $7^{\circ} \mathrm{C}$ to $18^{\circ} \mathrm{C}$. Samples $27-1 \mathrm{~F}$ and 27 $2 F$ experienced $0.2775 \mathrm{~g} / \mathrm{cm}^{2}$ and $0.2900 \mathrm{~g} / \mathrm{cm}^{2}$ mass losses, respectively, as compared to $0.2400 \mathrm{~g} / \mathrm{cm}^{2}$ for Sample 27-2M. This trend was observed in Samples 29-1F and 29-2F as compared to Sample 29-2M. These experiments also confirm the potential of the proposed technique for field applications.

As mentioned earlier, soil was autoclaved before sample preparation in order to ensure that the observed changes in wind erosion potential were solely derived from biocementation by the specified bacteria. The only exception was Sample 27U that was prepared similar to Sample 27-2M, except with unautoclaved soil. The results indicated a mass loss of $0.1250 \mathrm{~g} / \mathrm{cm}^{2}$ for Sample 27U as compared with $0.2400 \mathrm{~g} / \mathrm{cm}^{2}$ reported for Sample 27-2M. This can be an indication of encouraging further research to examine the effect of different treatment conditions on unautoclaved samples.

Considering the fact that $B$. amyloliquefaciens stabilizes the soil by calcium carbonate crystals formation, two samples were treated with lime in order to compare the efficiency of the two methods. By using hydrated lime, the following reaction is expected:

$$
\mathrm{Ca}(\mathrm{OH})_{2}+\mathrm{CO}_{2} \rightarrow \mathrm{CaCO}_{3} \downarrow+3 \mathrm{H}_{2} \mathrm{O} .
$$

Hence, Samples 27A and 29A were treated by spraying 
$2 \mathrm{~g}$ and $4 \mathrm{~g}$ of hydrated lime with $80 \mathrm{cc}$ and $60 \mathrm{cc}$ of water, respectively (other conditions are illustrated in Table 2). Wind tunnel erosion tests with sand bombardment on Samples $27 \mathrm{~A}$ and 29 A were performed, and their mass losses were $5.4600 \mathrm{~g} / \mathrm{cm}^{2}$ and $1.7950 \mathrm{~g} / \mathrm{cm}^{2}$, respectively. This large amount of eroded soil may have a connection with the difference in the nature of surface biocementation bonding as compared to hydrated lime bonding.
The results of wind erosion tests with disturbed soil surface (Group C tests) are illustrated in Table 4 . This table includes results of 24 main samples (rows 1 to 24) and 9 negative control samples (rows 25 to 33). This group of tests was carried out to investigate whether it is feasible to compare the results of wind erosion tests on samples containing disturbed soil surface (Group C tests) with the results of tests on undisturbed samples with sand bombardment

Table 4. Specifications and results of Group C tests.

\begin{tabular}{|c|c|c|c|c|c|c|c|c|c|}
\hline \multirow{2}{*}{\multicolumn{2}{|c|}{$\begin{array}{c}\text { Sample } \\
\text { no. }\end{array}$}} & \multicolumn{5}{|c|}{ Treatment } & \multirow[b]{2}{*}{$\begin{array}{c}\text { Mass } \\
\text { loss } \\
\left(\mathrm{g} / \mathrm{cm}^{2}\right)\end{array}$} & \multirow[b]{2}{*}{$\begin{array}{c}\text { Remediation } \\
(\%)\end{array}$} & \multirow[b]{2}{*}{ Comment } \\
\hline & & $\begin{array}{c}\text { Temperature } \\
\left({ }^{\circ} \mathrm{C}\right)\end{array}$ & $\begin{array}{c}\text { Bacteria } \\
\text { concentration } \\
(\text { O.D. })\end{array}$ & $\begin{array}{l}\text { Nutrient } \\
\text { (g/sample) }\end{array}$ & $\begin{array}{c}\text { Water } \\
\text { (g/sample) }\end{array}$ & $\begin{array}{c}\text { Curing } \\
\text { (days) }\end{array}$ & & & \\
\hline 1 & $1-1$ & 28 & 0.75 & 2 & 60 & 3 & 0.2325 & 92.1 & Main test \\
\hline 2 & $2-1$ & 28 & 0.75 & 2 & 60 & 3 & 0.2675 & 90.9 & Main test \\
\hline 3 & $14-1$ & 28 & 1.5 & 4 & 60 & 7 & 0.2500 & 91.5 & Main test \\
\hline 4 & $15-1$ & 28 & 1.5 & 4 & 80 & 3 & 0.1125 & 96.2 & Main test \\
\hline 5 & $23-1$ & 37 & 0.75 & 4 & 80 & 3 & 0.0575 & 98.0 & Main test \\
\hline 6 & $26-1$ & 37 & 1.5 & 2 & 60 & 7 & 0.1625 & 94.5 & Main test \\
\hline 7 & $27-1$ & 37 & 1.5 & 2 & 80 & 3 & 0.2200 & 92.5 & Main test \\
\hline 8 & $29-1$ & 37 & 1.5 & 4 & 60 & 3 & 0.5150 & 82.5 & Main test \\
\hline 9 & $18-1$ & 37 & 0.75 & 2 & 60 & 7 & 0.5425 & 81.5 & Main test \\
\hline 10 & $4-1$ & 28 & 0.75 & 2 & 80 & 7 & 0.0275 & 99.1 & Main test \\
\hline 11 & $32-1$ & 37 & 1.5 & 4 & 80 & 7 & 0.1400 & 95.2 & Main test \\
\hline 12 & $16-1$ & 28 & 1.5 & 4 & 80 & 7 & 0.0625 & 97.9 & Main test \\
\hline 13 & $1-2$ & 28 & 0.75 & 2 & 60 & 3 & 0.6825 & 76.8 & Main test \\
\hline 14 & $2-2$ & 28 & 0.75 & 2 & 60 & 3 & 0.1100 & 96.3 & Main test \\
\hline 15 & $14-2$ & 28 & 1.5 & 4 & 60 & 7 & 0.1100 & 96.3 & Main test \\
\hline 16 & $15-2$ & 28 & 1.5 & 4 & 80 & 3 & 0.0350 & 98.8 & Main test \\
\hline 17 & $23-2$ & 37 & 0.75 & 4 & 80 & 3 & 0.0875 & 97.0 & Main test \\
\hline 18 & $26-2$ & 37 & 1.5 & 2 & 60 & 7 & 0.2150 & 92.7 & Main test \\
\hline 19 & $27-2$ & 37 & 1.5 & 2 & 80 & 3 & 0.1425 & 95.1 & Main test \\
\hline 20 & $29-2$ & 37 & 1.5 & 4 & 60 & 3 & 1.0625 & 63.8 & Main test \\
\hline 21 & $18-2$ & 37 & 0.75 & 2 & 60 & 7 & 0.4175 & 85.8 & Main test \\
\hline 22 & $4-2$ & 28 & 0.75 & 2 & 80 & 7 & 0.1150 & 96.1 & Main test \\
\hline 23 & $32-2$ & 37 & 1.5 & 4 & 80 & 7 & 0.5750 & 80.4 & Main test \\
\hline 24 & $16-2$ & 28 & 1.5 & 4 & 80 & 7 & 0.0250 & 99.1 & Main test \\
\hline 25 & U1 & - & - & - & - & - & 2.7575 & 6.1 & No treatment \\
\hline 26 & $\mathrm{U} 2$ & - & - & - & - & - & 2.9375 & 0.0 & No treatment \\
\hline 27 & $45-1$ & 28 & 1.5 & - & 80 & 3 & 0.3225 & 89.0 & Negative control \\
\hline 28 & $45-2$ & 28 & 1.5 & - & 80 & 3 & 0.2050 & 93.0 & Negative control \\
\hline 29 & $44-1$ & 28 & 0.75 & - & 80 & 3 & 0.0925 & 96.9 & Negative control \\
\hline 30 & $44-2$ & 28 & 0.75 & - & 80 & 3 & 0.2375 & 91.9 & Negative control \\
\hline 31 & $35-2$ & 28 & - & 2 & 80 & 3 & 2.6800 & 8.8 & Negative control \\
\hline 32 & $39-1$ & 28 & - & - & 80 & 3 & 2.4275 & 17.4 & Negative control \\
\hline 33 & $39-2$ & 28 & - & - & 80 & 3 & 1.3450 & 54.2 & Negative control \\
\hline
\end{tabular}


(Group B tests). Unfortunately, considerable variation in mass loss was observed for identical samples in Group C. For instance, Samples 1-1, 1-2, 2-1, and 22 (which are the samples with the same treatment) showed $0.2325 \mathrm{~g} / \mathrm{cm}^{2}, 0.6825 \mathrm{~g} / \mathrm{cm}^{2}, 0.2675 \mathrm{~g} / \mathrm{cm}^{2}$, and $0.1100 \mathrm{~g} / \mathrm{cm}^{2}$ mass losses, respectively. This variation can only be attributed to different disturbance conditions of soil surface. Consequently, making a correlation between Group $\mathrm{C}$ results and Group B results sounds difficult. However, other results can be inferred from Group $\mathrm{C}$ tests as follows:

1. Untreated Samples U1 and U2 with respectively $2.7575 \mathrm{~g} / \mathrm{cm}^{2}$ and $2.9375 \mathrm{~g} / \mathrm{cm}^{2}$ mass losses experienced the highest erosion in this group of tests. To compare these values with treated samples in the same group, it can be concluded that formation of surface crust from biocementation in the proposed method prevents enlargement of disturbed area and, thus, considerably reduces the wind erosion potential;

2. Samples 35-2 (negative control of bacteria factor) as well as 39-1 and 39-2 (negative control of bacteria and nutrient factors) had $2.6800 \mathrm{~g} / \mathrm{cm}^{2}$, $2.4275 \mathrm{~g} / \mathrm{cm}^{2}$, and $1.3425 \mathrm{~g} / \mathrm{cm}^{2}$ mass losses, respectively. These mass losses are significantly larger than typical mass losses in the main samples (between $0.0250 \mathrm{~g} / \mathrm{cm}^{2}$ to $0.6825 \mathrm{~g} / \mathrm{cm}^{2}$ ). Again, the efficiency of the proposed method is confirmed in the case of disturbed soil surface.

The formation of calcium carbonate in soil samples was explored by XRD analysis. The results are shown in Figure 5 and Figures A.1 and A.2. A comparison of carbonate peaks $(2 \Theta=29.5,47.6,48.6)$ for treated and untreated samples clearly shows higher calcium carbonate content in the treated sample.

To further explore the formation of calcium carbonate in soil samples, several Calcium Carbonate Equivalent (CCE) tests were performed. Percentages of carbonate calcium equivalent were determined as 62.5 , 62.75, and 68.5 for Samples 23-1, 14-1M, and 1-1 before treatment, respectively, and the corresponding values for the same samples after treatment were $63.25,64.5$, and 68.75. The results indicated that the treated samples had relatively higher calcium carbonate content.

Furthermore, Scanning Electron Microscopy (SEM) was employed to investigate the role of biocementation and bonding between soil particles. Figure 6 illustrates the images of treated and untreated samples with $\times 100$ and $\times 500$ magnification. These images confirm the formation of carbonate on the surface as well as at particle contacts.

\section{Conclusion}

An attempt was made to study the performance of

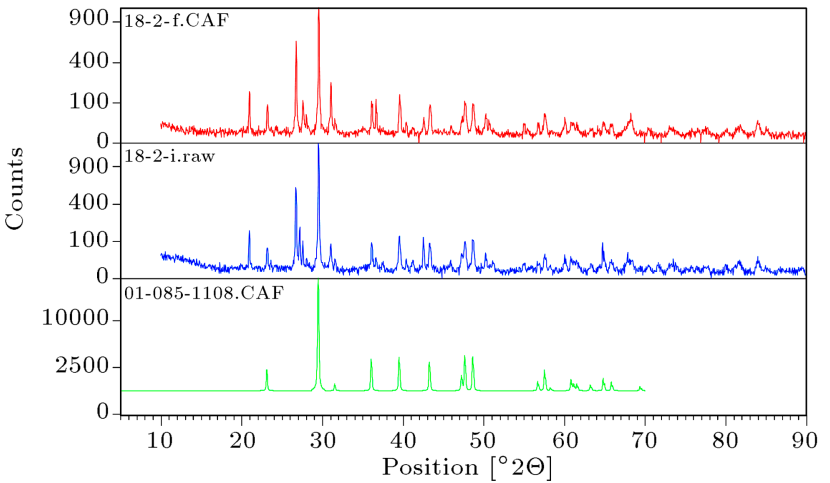

(a)

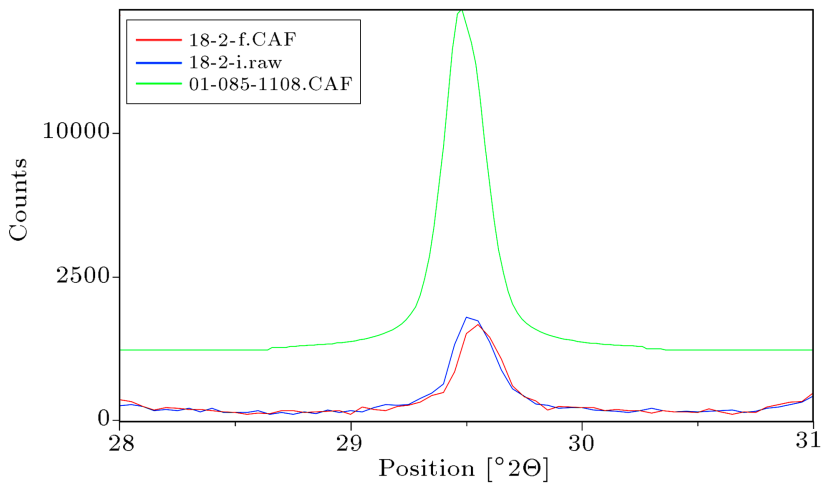

(b)

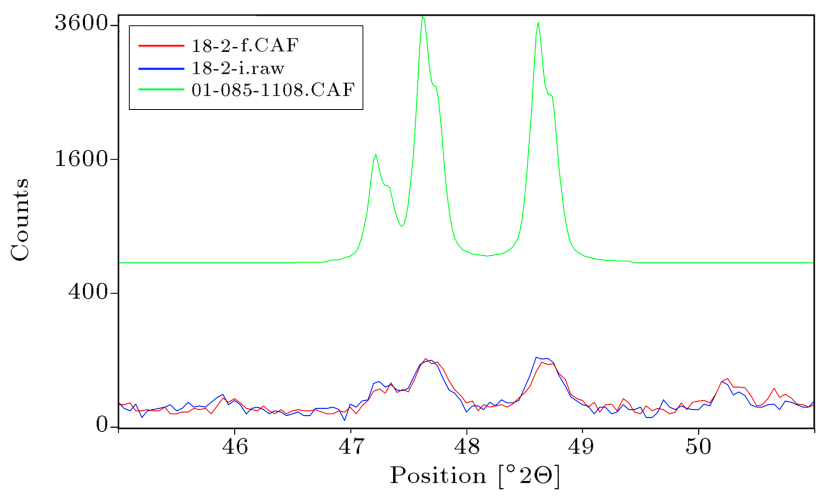

(c)

Figure 5. XRD analysis (a) Example of XRD peaks ( upper: Sample 18-2 before treatment, middle: Sample 18-2 after treatment, lower: reference code of calcite). (b) Main peak $(2 \theta=29.5)$ of calcite before and after treatment for $18-2$ sample. (c) two main peaks $(2 \theta=47.6$, 48.6) of calcite before and after treatment for Sample 18-2.

biological calcium carbonate cementation as a soil stabilization technique using a heterotrophic bacterium, B. amyloliquefaciens. The bacterium used in the present investigation has the advantage of producing environmental-friendly by-products as compared to some other bacteria used in the past.

The proposed method was tested on a laboratory scale using a closed-circuit wind tunnel. Three main groups of samples were tested: (1) undisturbed soil surface and without sand bombardment (Group A), (2) undisturbed soil surface and with sand bombardment 


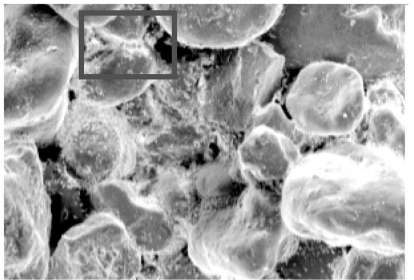

(a)

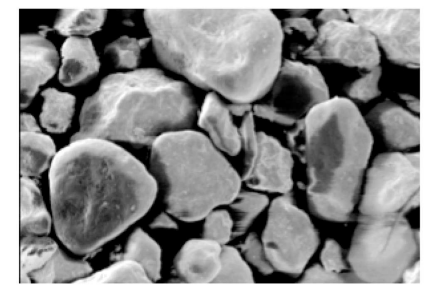

(c)

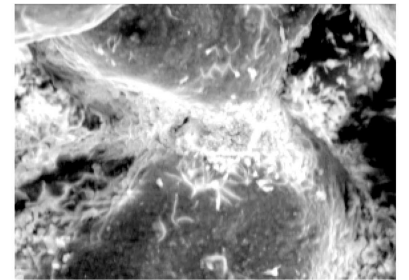

(b)

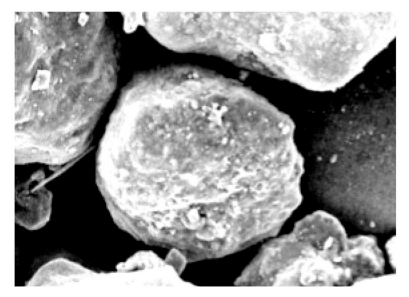

(d)
Figure 6. SEM images of a treated soil sample, magnification: (a) $\times 100$; (b) $\times 500$ and untreated soil sample, magnification; (c) $\times 100 ;$ (d) $\times 500$.

(Group B), and (3) with disturbed soil surface and without sand bombardment (Group C).

Group A tests showed that treated soils were stabilized against erosion with wind velocities up to $30 \mathrm{~m} / \mathrm{s}$. The maximum amount of erosion measured for this group of tests was about $0.01 \mathrm{~g} / \mathrm{cm}^{2}$.

From Group B tests, the following conclusions are drawn:

1. Generally, the biocement calcium carbonate crusts preserved their structure under sand bombardment condition with wind velocities up to $14 \mathrm{~m} / \mathrm{s}$ to $15 \mathrm{~m} / \mathrm{s}$ with minor surface erosion. Sand bombardment flux was kept at $120 \mathrm{~g} / \mathrm{min}$ during all tests. Therefore, the authors believe that the proposed technique has the potential of field application;

2. Among the five factors, temperature, bacteria concentration, amount of nutrient, amount of water, and curing time as well as two-factor interactions, curing time, water, temperature-water, and bacteria-water were statistically significant factors and interactions for suppressing wind erosion;

3. In the investigated range of curing times ( 3 to 7 days), the increase of curing time led to a decrease in mass loss. Therefore, the field application of the present method will be efficient if there is a suitable safe margin of time between treatment application and possible erosive wind;

4. Two levels for water solution were adopted, and soil samples were sprayed with water solution of 1.5 and $2 \mathrm{lit} / \mathrm{m}^{2}$, which is equal to 60 and $80 \mathrm{cc} / \mathrm{sample}$. From test results, the following can be concluded:

(a) In the case of $80 \mathrm{cc}$ water solution, the increase of temperature had no negative effect on performance of the proposed method. However, in the case of lower amount of water solution (60 cc/sample), an increase in temperature led to an increase in soil erosion;

(b) By using the upper level for water solution, soil erodibility was reduced with an increase in bacteria concentration. In contrary, for the lower level of water solution, the increase of bacteria concentration did not improve the performance of the proposed technique.

5. Negative control tests in this group, which included bacteria and nutrient negative control, bacteria negative control, and also nutrient negative control, confirmed the results of the main tests, that is, bacteria contribute as a controlling factor, while nutrient does not;

6. Results of tests on outdoor treated samples as well as test results from laboratory samples cured at temperatures as high as $50^{\circ} \mathrm{C}$ indicate that uncontrolled field temperature may not be considered as a limitation for the proposed method;

7. Mass loss in lime treated samples was very significant; therefore, lime treatment was not considered as an effective technique for the soil studied in this investigation.

Group $\mathrm{C}$ tests indicated that surface biocementation crusts could reduce wind erosion of soil even in the case of partial disturbance.

To sum up, based on laboratory tests, it is concluded that the proposed method can serve as a promising technique to suppress wind erosion and sand dust in susceptible zones. However, researchers are encouraged to carry out pilot field tests to study the influence of ambient condition and long-term duration on performance of the method.

\section{Acknowledgments}

The authors are grateful for the financial support of Iran National Science Foundation (INSF) Grant no. 93039407. The first author would like to thank the team of Biotechnology Research Center of Shiraz University, particularly, Mrs. Aram and Mr. Farahmand for their help in laboratory activities and also $\mathrm{Mr}$. Alizadeh for his help in wind tunnel tests.

\section{References}

1. Shao, Y., Physics and Modelling of Wind Erosion, 37, Springer, London (2008).

2. Shahsavani, A., Yarahmadi, M., Mesdaghinia, A., Younesyan, M., Jaafarzadeh, N.A., Naeemabadi, A., Salesi, M., and Nadafi, K. "Analysis of dust storms entering Iran with emphasis on Khuzestan province", Hakim Res, 3, pp. 192-202 (2012). 
3. Refahi, H., Wind Erosion and its Control, Tehran University, Tehran (2004).

4. Maleki, M., Ebrahimi, S., Asadzadeh, F., and Tabrizi, M.E. "Performance of microbial-induced carbonate precipitation on wind erosion control of sandy soil", Int. J. Environ Sci Technol, 13, pp. 937-944 (2016).

5. Mortensen, B.M., Haber, M.J., DeJong, J.T., Caslake, L.F., and Nelson, D.C. "effects of environmental factors on microbial induced calcium carbonate precipitation", Journal of Applied Microbiology, 111, pp. 338349 (2011).

6. Rebata-Landa, V. "Microbial activity in sediments: Effects on soil behavior", Dissertation, Georgia Institute of Technology (2007).

7. Ivanov, V. and Chu, J. "Applications of microorganisms to geotechnical engineering for bioclogging and biocementation of soil in situ", Rev. Environ. Sci. Bio/Technol, 7(2), pp. 139-153 (2008).

8. Dejong, J.T., Soga, K., Kavazanjian, E., et al. "Biogeochemical processes and geotechnical applications: Progress, opportunities, and challenges", Geotechnique, 63(4), pp. 287-301 (2013).

9. Bang, S., Min, S.H., and Bang, S.S. "Application of microbiologically induced soil stabilization technique for dust suppression", Int. J. Geo-Eng, 3(2), pp. 27-37 (2011).

10. Stabnikov, V., Chu, J., Myo, A.N., and Ivanov, V. "Immobilization of sand dust and associated pollutants using bioaggregation", Water Air Soil Pollut, 224(9), pp. 1-9 (2013).

11. Anderson, J., Bang, S.S., Bang, S., Lee, S.J., Dho, N.Y., Choi, S.R., and Ko, S. "Application of microbial calcite to fiber reinforced soils to reduce wind erosion potential", Int. J. Geo-Eng, 4(2), pp. 47-54 (2012).

12. Liu, Y., Cockell, C.S., Wang, G., Hu, C., Chen, L., and De Philippis, R. "Control of lunar and martian dust-experimental insights from artificial and natural cyanobacterial and algal crusts in the desert of Inner Mongolia, China", Astrobiol, 8(1), pp. 75-86 (2008).

13. Meyer, F., Bang, S., Min, S., Stetler, L., and Bang, S. "Microbiologically-induced soil stabilization: application of Sporosarcina pasteurii for fugitive dust control", Proc Geo-Frontiers, pp. 4002-4011 (2011).

14. O'Brien, P. and Neuman, C.M. "A wind tunnel study of particle kinematics during crust rupture and erosion", Geomorphol, 173, pp. 149-160 (2012).

15. Cuadros, J., Spiro, B., Dubbin, W., and Jadubansa, P. "Rapid microbial stabilization of unconsolidated sediment against wind erosion and dust generation", J. Soils Sediments, 10(7), pp. 1415-1426 (2010).

16. Neuman, C.M. and Maxwell, C. "A wind tunnel study of the resilience of three fungal crusts to particle abrasion during aeolian sediment transport", Catena, 38(2), pp. 151-173 (1999).

17. Knorr, B.M. "Enzyme-induced carbonate precipitation for the mitigation of fugitive dust", Thesis, Arizona State University (2014).
18. Alsanad, A. "Novel biopolymer treatment for wind induced soil erosion", Dissertation, Arizona State University (2011).

19. Strong C.L. "Effects of soil crusts on the erodibility of a claypan in the channel country, South-West Queensland, Australia", Dissertation, Griffith University (2007).

20. Bagnold, R.A., The Physics of Blown Sand and Desert Dunes, Methuen, London (1941).

21. Scott, W.D. "Measuring the erosivity of the wind", Catena, 24, pp. 163-175 (1995).

22. Shao, Y., Raupach, M.R., Leys, J.F. "A model for predicting aeolian sand drift and dust entrainment on scales from paddock to region", Soil Res, 34(3), pp. 309-342 (1996).

23. Irwin, H.P.A.H. "The design of spires for wind simulation", J. Wind Eng. Ind. Aerodyn, 7(3), pp. 361-366 (1981).

24. Neuman, C.M., Maxwell, C.D., and Boulton, J.W. "Wind transport of sand surfaces crusted with photoautotrophic microorganisms", Catena, 27(3), pp. 229-247 (1996).

25. Langston, G. and Neuman, C.M. "An experimental study on the susceptibility of crusted surfaces to wind erosion: A comparison of the strength properties of biotic and salt crusts", Geomorphol, 72(1), pp. 40-53 (2005).

26. Rice, M.A. and McEwan, I.K. "Crust strength: a wind tunnel study of the effect of impact by saltating particles on cohesive soil surfaces", Earth Surf Process Landf, 26(7), pp. 721-733 (2001).

27. Zobeck, T.M. "Abrasion of crusted soils: Influence of abrader flux and soil properties", Soil Sci Soc Am J, 55(4), pp. 1091-1097 (1991).

28. Houser, C.A. and Nickling, W.G. "The factors influencing the abrasion efficiency of saltating grains on a clay-crusted playa", Earth Surf Process Landf, 26(5), pp. 491-505 (2001).

\section{Appendix}

XRD Analysis Results.

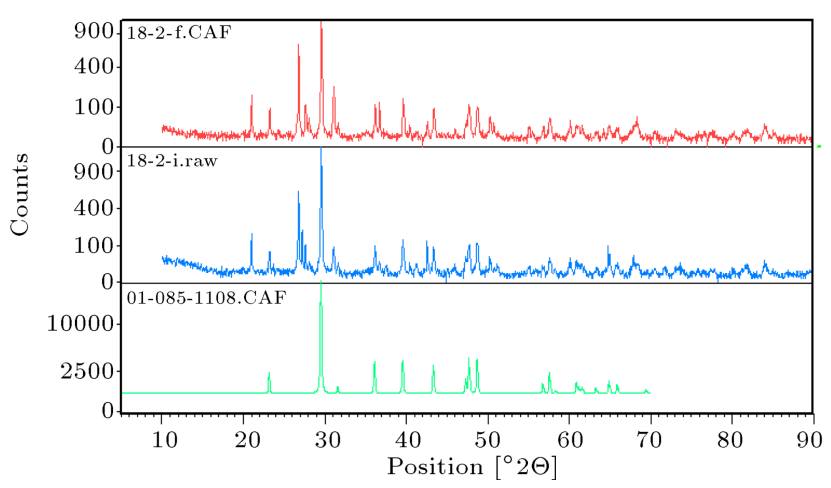

Figure A.1. XRD analysis (upper: Sample 18-1 before treatment, middle; Sample 18-1 after treatment, lower: reference code of calcite). 


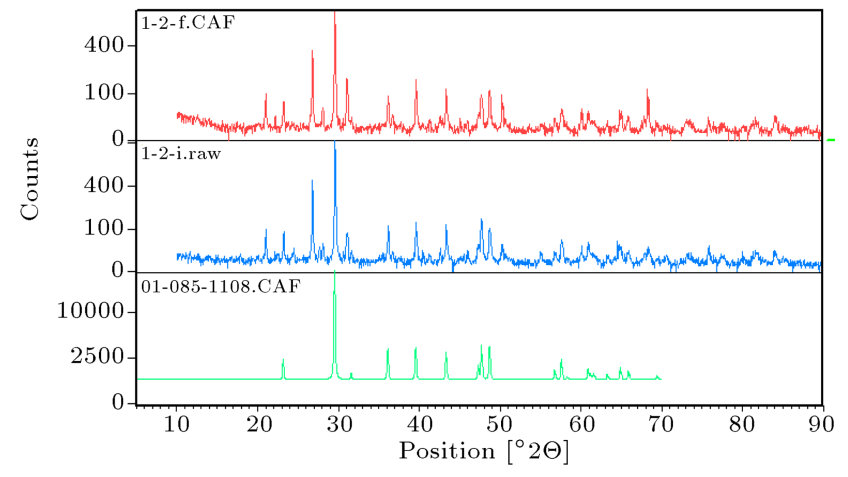

Figure A.2. XRD analysis (upper: Sample 1-2 before treatment, middle; Sample 1-2 after treatment, lower: reference code of calcite).

\section{Biographies}

Mohammad Mehdi Mohebbi received his MS in Geomechanics from Tehran University in 2004 and has been working on his $\mathrm{PhD}$ thesis since 2013. He has published 5 papers in credited journals and international conference proceedings.

Ghassem Habibagahi is a Professor at the Department of Civil and Environmental Engineering at Shiraz
University. His research interests include unsaturated soil mechanics, geoenvironmental engineering, and embankment dam engineering. He received his $\mathrm{PhD}$ degree from Montreal University in 1991. He has published more than 50 papers in the field of soil mechanics in international journals and conference proceedings.

Ali Niazi is a Professor at the Department of Biotechnology at Shiraz University. His research interests include molecular genetics, genetic engineering, and biotechnology. He received his $\mathrm{PhD}$ degree from Tarbiat Modarres University in 2004. He has published more than 165 papers in international journals and conference proceedings.

Arsalan Ghahramani received his $\mathrm{PhD}$ degree from the Department of Civil and Environmental Engineering at the University of Princeton in 1967. He is currently a Professor of Geotechnical Engineering at the Civil Engineering Department of Shiraz University. He has published more than 70 papers in international journals and international conference proceedings. He was also selected as one of "distinguished figures" of the Iranian scientific community in 2008. 